\title{
Probable Helicase Senataxin
}

National Cancer Institute

\section{Source}

National Cancer Institute. Probable Helicase Senataxin. NCI Thesaurus. Code C124951.

Probable helicase senataxin (2677 aa, $\sim 303 \mathrm{kDa}$ ) is encoded by the human SETX gene.

This protein is involved in nucleic acid processing. 